\title{
O JEDNOM TRGU I DVA SPOMENIKA - RATNOM SPOMENIKU I GRGURU NINSKOM
}

\author{
Vladimir HUZJAN \\ Zavod za znanstveni rad HAZU u Varaždinu \\ Varaždin, Hrvatska
}

\author{
UDK: 904 : 711.61(497.523 Varaždin) \\ DOI: https://dx.doi.org/10.21857/ypn4oc8de9 \\ Izvorni znanstveni rad \\ Prihvaćeno: 17. svibnja 2019.
}

U ovome radu autor piše o dva spomenika na varaždinskom Franjevačkom trgu. Prvi je bio austrougarski Ratni spomenik Artura Kadeŕaveka postavljen 1915. koji je 1931. zamijenio Grgur Ninski Ivana Meštrovića. U prilogu su i prijepisi dva govora: prvi varaždinskog župana Stjepana pl. Beloševića na otkrivanju Ratnog spomenika, a drugi zagrebačkog nadbiskupa Antuna Bauera pri otkriću Grgura Ninskog. Oba govora prikazuju duh vremena kada su spomenici postavljeni.

Ključne riječi: Varaždin, I. svjetski rat, Ivan Meštrović, Artur Kadeŕavek, Grgur Ninski.

\section{UVOD}

Prostor ispred Franjevačke crkve u Varaždinu ukrašen je dvama spomenicima - jednim koji je veličao uspjehe, čvrstoću i nedjeljivost dvojne monarhije, a drugi slavenski otpor i jedinstvo. U međuvremenu je prvi srušen, a drugi je postao najmonumentalnija skulptura u Gradu Varaždinu. Godine 2008., kada su provedena arheološka istraživanja Franjevačkog trga, u neposrednoj blizini Grgura Ninskog otkriven je ostatak Ratnog spomenika. On je danas izložen i objašnjen prigodnom informativnom pločom. ${ }^{1}$ Tako je Varaždin postao jedan od rijetkih gradova u Hrvatskoj koji je javno predstavio austro-ugarski spomenik iz razdoblja Velikog rata.

\section{VARAŽDIN 1915. GODINE}

Grad Varaždin ušao je u I. svjetski rat kao slobodni i kraljevski grad u sastavu Varaždinske županije. ${ }^{2}$ U ožujku 1914. održani su gradski izbori na kojima je pobijedila hrvatsko-srpska koalicija, a gradonačelnikom je imenovan dr. Pero

1 U lipnju 2014., a u povodu obilježavanja 100. godišnjice početka Velikog rata, dio spomenika je uz informativnu ploču postavio Gradski muzej Varaždin.

2 Više vidi u: Đurđica CESAR, Pregled povijesti Varaždina u prvoj polovici dvadesetoga stoljeća, Franjo Košćec i njegovo djelo (1882.-1968.), Hrvatska akademija znanosti i umjetnosti, Zavod za 
Magdić (1863. - 1922.) koji će na tom mjestu ostati do kraja rata. Objavom rata u Varaždin je uvedena cenzura, zabrana djelovanja političkih stranaka, okupljanja, mobilizacija i prijeki sud. Ubrzo su se povećale cijene i pojavila se nestašica šećera, mesa, masti, jaja, drva za grijanje, petroleja itd. Da bi se nekako obuzdao rast cijena, Grad je osnovao Odbor za tržne cijene živežnim namirnicama.

Već u prvim mjesecima rata u grad su pristizali ranjenici s južnog i istočnog bojišta koji su smješteni u gradsku bolnicu. O njima su brinuli i volonteri, a za lokalne udovice i siročad pokrenuta je humanitarna akcija „Dadoh zlato za željezo“. Uz ranjenike su u grad pristizali i vojni zarobljenici, raspoređeni u trgovine, proizvodnju i na seoska imanja, kao i civili iz Srijema, tzv. internirci. ${ }^{3}$ Usporedno s tim, za sve poginule vojnike Grad je odredio da se besplatno pokopaju na lokalnom groblju. To je mjesto prigodno izdvojeno, a 2018., kada se obilježavala 100. godišnjica završetka Velikog rata, i prigodno obilježeno. ${ }^{4}$

U različitim razdobljima Velikog rata na varaždinskom području djelovalo je nekoliko karitativnih organizacija koje su brinule o stacioniranim ranjenicima ili vojnicima u prolazu poput podružnice Crvenog križa, skautske i učeničke organizacije $\mathrm{e}^{5}$ ili Zaklade za nemoćne vojnike iz svjetskog rata od god. 1914./1915.

znanstveni rad u Varaždinu, Gradski muzej Varaždin, Gimnazija Varaždin, Hrvatsko entomološko društvo, Zagreb - Varaždin, 2008., 1 - 15; Višnja BUREK, Djelovanje poglavarstva Grada Varaždina u ratnim godinama 1914. i 1915., Varaždin i sjeverozapadna Hrvatska u Velikom ratu 1914.-1918., zbornik radova sa znanstvenog skupa s međunarodnim sudjelovanjem održanim u Varaždinu 3. i 4. srpnja 2014., Hrvatska akademija znanosti i umjetnosti, Zavod za znanstveni rad u Varaždinu, Zagreb - Varaždin, 2014., 273. - 301; Spomenka TeŽAK, Veliki rat na varaždinskom području, Narod u nevolji. Veliki rat na varaždinskom području, Gradski muzej Varaždin, 2014., 9 - 38; Petra MARINCEL, Gospodarski život grada Varaždina, Narod u nevolji. Veliki rat na varaždinskom području, Gradski muzej Varaždin, 2014., 39 - 48.

3 Za zbivanja u Varaždinu i na području sjeverozapadne Hrvatske tijekom I. svjetskog rata vidi zbornik radova: Varaždin i sjeverozapadna Hrvatska u Velikom ratu 1914. - 1918., Hrvatska akademija znanosti i umjetnosti, Zavod za znanstveni rad u Varaždinu, Zagreb - Varaždin, 2014.

4 Vidi i: Vladimir HuzjaN, Vojne žrtve velikog rata i poraća pokopane na varaždinskom groblju (1914. - 1919.), Radovi Zavoda za znanstveni rad Varaždin, 29, Zagreb - Varaždin, 2018., 179 - 222; Vladimir Huzjan, Jasmin Medved, O korisnicima obiteljskih invalidnina sudionika Prvoga svjetskog rata - popis Narodnog odbora kotara Varaždin, Radovi Zavoda za znanstveni rad Varaždin, 25, 2014., 479 - 551; Vladimir Huzjan, Jasmin Medved, O korisnicima osobnih invalidnina sudionika Prvoga svjetskog rata - popis Narodnog odbora kotara Varaždin, Varaždin i sjeverozapadna Hrvatska u Velikom ratu 1914. - 1918., Zagreb - Varaždin, Hrvatska akademija znanosti i umjetnosti, 2014., 189 - 246; Vladimir HUZJAN, O ranjenicima i zarobljenicima u Varaždinu 1914. i 1915. te invalidima i ratnom groblju nakon Velikog rata, Varaždin $i$ sjeverozapadna Hrvatska u Velikom ratu 1914. - 1918., Zagreb - Varaždin: Hrvatska akademija znanosti i umjetnosti, 2014., 161 - 188.

5 Siniša Horvat, Djelovanje varaždinske sveučilišne i srednjoškolske mladeži tijekom Prvoga svjetskog rata, Varaždin i sjeverozapadna Hrvatska u Velikom ratu 1914. - 1918., Hrvatska akademija znanosti i umjetnosti, Zavod za znanstveni rad u Varaždinu, Zagreb - Varaždin, 2014., 
županije varaždinske i kr. i slob. grada Varaždina. ${ }^{6}$ Upravo je najznačajniji uspjeh ove Zaklade bilo podizanje Ratnog spomenika.

\section{RATNI SPOMENIK}

Prikupljanjem novčanih sredstava i praćenjem napretka bavio se Odbor za podignuće Ratnoga spomenika u gradu Varaždinu pod vodstvom varaždinskog župana Stjepana pl. Beloševića (1857. - 1935.), a svrha mu je bila prikupiti novčana sredstava za nemoćne vojnike i njihove obitelji kupnjom zlatnih, srebrnih, bakrenih ili željeznih čavala, koliko je tko uplatio, a koji su se zabijali u drvenu ploču na spomeniku. ${ }^{7}$

Spomenik je izrađen od umjetnog kamena, a sličio je na obelisk, prema zamisli lokalnog arhitekta Artura Kadeŕaveka (1883. - 1963.). Dvjema stepenicama dolazi se do visokog podnožja spomenika iznad kojeg slijedi središnji dio kubus, ukrašen $s$ tri strane austrijskim odlikovanjem - Križem za vojne zasluge s ratnom dekoracijom od drva u koji su se zabijali čavli. Na četvrtoj strani ostavljeno je mjesto za prigodnu spomen-ploču koja bi se tu postavila nakon rata. Kubus je okružen željeznim lancima. Iznad križeva su u željezu ispisane godine rata - 1914., 1915. i 1916. Iznad središnjeg djela je manji kubus ukrašen grbovima Varaždinske županije i Grada Varaždina koje nadvisuje kruna sv. Stjepana. Na samom vrhu je globus s četiri orla postavljena na sve četiri strane svijeta, a ispod je prigodni natpis u željezu „SVJETSKI RAT“.

349 - 370; Siniša HoRvat, Djelovanje varaždinskih gimnazijskih skauta početkom Prvog svjetskog rata, Radovi Zavoda za znanstveni rad Varaždin, Hrvatska akademije znanosti i umjetnosti, Zavod za znanstveni rad u Varaždinu, Zagreb - Varaždin, 2017., 28, 379 - 391; Siniša HoRvat, Doprinos varaždinske mladeži dobrotvornim aktivnostima tijekom Prvog svjetskog rata, Radovi Zavoda za znanstveni rad Varaždin, Hrvatska akademije znanosti i umjetnosti, Zavod za znanstveni rad u Varaždinu, Zagreb-Varaždin 2017., 28, 393 - 414.

6 Magdalena LoNČArić, Dobrotvorna djelatnost i humanitarne akcije u Varaždinu i Županiji varaždinskoj tijekom Prvoga svjetskog rata, Varaždin i sjeverozapadna Hrvatska u Velikom ratu 1914. - 1918., Hrvatska akademija znanosti i umjetnosti, Zavod za znanstveni rad u Varaždinu, Zagreb - Varaždin, 2014., 407 - 430.

7 Ratni spomenik u Varaždinu, Hrvatsko pravo, 4. prosinca 1915., 3; Zabijanje čavala u ratni spomenik, Hrvatsko pravo, 18. prosinca 1915., 3.

8 Kako izgleda varaždinski ratni spomenik, Hrvatsko pravo, 18. prosinca 1915., 2; Ana KANIšKI, Kulturni i umjetnički život grada Varaždina za Prvoga svjetskog rata, Varaždin i sjeverozapadna Hrvatska u Velikom ratu 1914. - 1918., zbornik radova sa znanstvenog skupa s međunarodnim sudjelovanjem održanim u Varaždinu 3. i 4. srpnja 2014., Hrvatska akademija znanosti i umjetnosti, Zavod za znanstveni rad u Varaždinu, Zagreb - Varaždin, 2014., 317 - 348; Spomenka TEŽAK, Veliki rat na varaždinskom području u katalogu: Narod u nevolji. Veliki rat na Varaždinskom području, Gradski muzej Varaždin, Varaždin, 2014., 19 - 20. 
Ratni spomenik postavljen je na Franjevačkom trgu između Franjevačke crkve i palače Hercer. Svečano otkrivanje bilo je 11. prosinca 1915. u 11 sati. „Samo otkriče uslijedilo je prema opredijeljenome svečanosnom redu, a nosilo je biljeg jedne lijepe uznosite slave." Okupljenima se prvi obratio župan S. pl. Belošević nakon čijeg je govora odsvirana carska himna. Poslije njega govorio je načelnik P. Magdić, a za njim je odsvirana hrvatska himna. Nakon ceremonije prve zlatne čavliće zabili su župan S. Belošević, koji je položio u Zakladu 5.000 kruna i 100 kruna u ime bana Ivana Skerlecza (1873. - 1951.), te gradonačelnik P. Magdić s dotacijom od 500 kruna. Toga dana prikupljeno je 6.017 kruna za Zakladu i oko 2.000 kruna za pokrivanje troška izrade spomenika. Doprinos su dali mnogi građani i trgovačka društva. ${ }^{10}$

Nakon predstavljanja Ratnog spomenika javnosti, Grad je vodio brigu o zabijanju čavla i prikupljanju novčanih sredstava. Cijena jednog čavla bila je 1 krunu, a kasnije je smanjena na 10 filira. To je pogodovalo masovnijim manifestacijama poput slučaja kada je učitelj iz Ivanca doveo oko 450 djece koja su kupila čavle i zabila ih u spomenik. ${ }^{11}$

Prikupljanje novaca za ratnu siročad i stradale vojnike trajalo je do kraja rata. Kada je Veliki rat završio, Varaždin je postao dio nove državne zajednice koja je raskinula gotovo osmostoljetne veze $s$ Kraljevinom Ugarskom i gotovo četiristoljetne veze s Carevinom Austrijom. U prvim danima vladalo je oduševljenje, no uskoro je uslijedilo razočaranje. Hrvatska je izgubila autonomnost i teritorijalnu cjelovitost koju je imala u Austro-Ugarskoj Monarhiji, a svakodnevicu je ometala žandarska, vojna i politička represija.

U Varaždinu je nova vlast pokrenula akciju uklanjanja Ratnog spomenika: „Ima nekih, koji hoće da se odstrani tek Verdienst, zardjali 'cveki' i onaj grb na vrhu, pak da se na nj postavi kakav drugi kip. Ovima dovikujemo odlučno: Ne! Gromada mora dolje, treba da se smrvi, raskida! Nećemo, da nas ma i najmanja čestica sjeti na krvavu prošlost, a lanci na ropstvo. Napokon, gradja je neukusna i nimalo ne pristaje uz crkvu, gdje se čuje riječ Kristova: Mir Vama! (...) Zato kladiva napolje, potrgajmo lance ropstva! Mi ćemo već namaći toliko novca, kojim ćemo moći, da podignemo dostojan spomenik Slobode! Rugoba od spomenika pred franjevačkom crkvom nije spomenik ratu, već spomenik ulizavanja, štreberstva i ropskog duha, koji je na žalost u jednom dijelu varaždinske gospode vladao. Kad

9 Posveta ratnog spomenika, Hrvatsko pravo, 11. prosinca 1915., 1.

10 Posveta ratnog spomenika, Hrvatsko pravo, 11. prosinca 1915., 2; Sjednica gradskog zastupstva, Hrvatsko pravo, 18. prosinca 1915., 2.

11 Seoska mladež iz Ivanca pred Ratnim spomenikom u Varaždinu, Hrvatsko pravo, 24. ožujka 1916., $2-3$. 


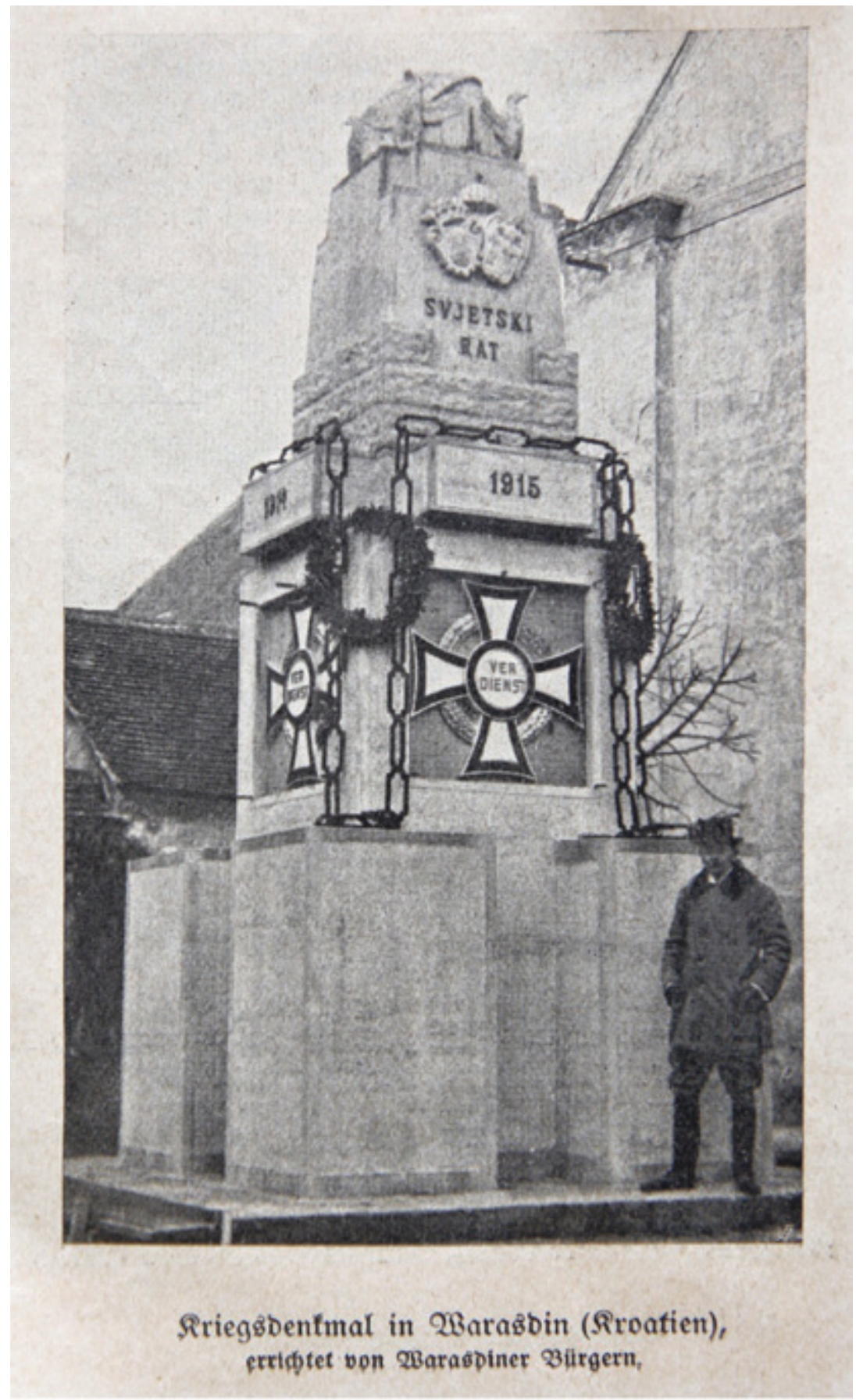

SLIKA 1. Ratni spomenik na varaždinskom Franjevačkom trgu (Gradski muzej Varaždin, 54451) 
je bivši veliki župan Belošević tu rugobu svečanim načinom otkrivao, preuzelo je gradsko poglavarstvo spomenik na čuvanje. Na njemu je da ga sada odstrani.“"12 Austro-ugarska obilježja maknuta su sa spomenika nedugo nakon rata, pretrpio je manja oštećenja, ali je ostao na mjestu do 1931 . godine. ${ }^{13}$

\section{VARAŽDIN 1931. GODINE}

Nakon proglašenja diktature, dotadašnji gradski načelnik Hinko Krizman (1881. - 1958.) dao je ostavku, a novu dužnost preuzeo je 27. ožujka 1929. Viktor Plazzeriano (1870. - 1938.). Od tada građani višu nisu birali gradsku upravu, već ju je imenovao ban kojeg je imenovao kralj. Okružni inspektor pratio je rad gradskog načelnika. Izvijestio je Bana da nema energije, često je bolestan i da ga gradski zastupnici iskorištavaju. Predložio je da ga zamijeni Dragutin Perko (1875. - 1945.) koji je 1925. bio gradski komesar te da je „(...) kao vlasnik lista Jugoslavija koji aktivno promiče političke poteze diktature kralja Aleksandra, najbolje političko rješenje za grad" ${ }^{14} \mathrm{Za}$ novog gradskog načelnika imenovan je 8. travnja 1931. godine.

Pri razgledavanju sjeverozapadne Hrvatske kralj Aleksandar (1888. - 1934.) posjetio je Varaždin 5. lipnja 1931., a gradska vlast učinila je sve da naglasi svoju odanost. Automobilom je prošao ispod slavoluka s natpisom: „Aleksandre, Varaždin je Tvoj“. ${ }^{15}$ Ipak, da bi se skupilo dovoljno ljudi na dočeku naređeno je da iz svakog sela dođu po dva odbornika, državni i gradski službenici, radnici iz tvornica te djeca iz škola. Kao novi gradski načelnik, D. Perko već je u kolovozu 1931. organizirao dvodnevnu svečanost u povodu 10. godišnjice stupanja kralja Aleksandra na prijestolje. U gradskom parku otkrivena je spomen-ploča kraj lipe koja je posađena u čast kraljeva vjenčanja, a park oko Starog grada prozvan je Parkom Kralja Aleksandra I. Ujedinitelja. U gradu je osnovan i ogranak društva Mlada Jugoslavija koje je za cilj imalo jačanje jugoslavenske svijesti. Kako je D. Perko bio izabran za narodnog poslanika, zamijenio ga je 7. siječnja 1932. Stjepan Novaković (1881. - 1966.).

12 Varaždinski Verdienst, Volja naroda, 14. studenoga 1918., 3.

13 „(...) pa rek bi da je rušenje Verdiensta već u punom jeku (...)“, I opet Grgur Ninski, Varaždinske novosti, 23. travnja 1931., 2.

14 Hrvatski državni arhiv (HDA), Okružni inspektorat Varaždin (OIV), Povjerljivi spisi (PS) 1931. Na dokumentu oznaka: br. 353/ Pov. 1931.

15 Kralj i narod. Trijumfalna putovanja Njegova Veličanstva Kralja po Savskoj banovini 1. VI.-18. VI. 1931., 34. 
Istaknutiji Varaždinci koji nisu podupirali kraljev režim bili su pod nadzorom, a bilo je raznih oblika otpora. U gimnaziji je netko stavio sliku kraljevske obitelji na pod i „,...) obavio na istoj svoju nuždu zagadivši (ju) vlastitim blatom“. ${ }^{16} \mathrm{Ili}$ kada je Antun Lazar, zapovjednik Vatrogasne župe Varaždin, pri posveti novog vatrogasnog doma u Sračincu zaustavio orkestar koji je svirao državnu himnu rekavši: „Sto vam bogova, što svirate! (...) Stoj! Sviraj L(j)epu našu (...) i ostale hrvatske pjesme, jer se nalazimo u Hrvatskoj domovini (...)!“"17 Upravo je u ovako napetim društveno-političkim okolnostima u Varaždinu podignut spomenik Grguru Ninskom. ${ }^{18}$

\section{GRGUR NINSKI}

Prema zapisima ravnatelja Gradskog muzeja Varaždin Krešimira Filića (1891. - 1972.), u muzeju se 1927. javila zamisao o osnutku lokalne galerije hrvatske moderne umjetnosti. Novaca za kupnju umjetnina nije bilo te su upućeni apeli umjetnicima neka doniraju svoja djela varaždinskoj galeriji. Tada je u Hrvatskoj postojala samo Akademijina Strossmayerova galerija i jedna u Splitu, a Varaždinska galerija bila bi treća. Prijedlog su prihvatili tadašnji ministar i kasniji gradski načelnik Hinko Krizman i njegov brat slikar Tomislav Krizman (1882. - 1955.). Obojica su razgovarali s I. Meštrovićem koji je ponudu prihvatio i odlučio Varaždinu donirati prvu verziju spomenika Grgur Ninski. ${ }^{19}$ Ukratko je prokomentirao: „Neka Grgur Ninski bude na Hrvatskom sjeveru kao i onaj na jugu u Splitu vidljivi dokaz na našu uspješnu borbu za crkvenoslavenski jezik i hrvatsku glagoljicu. ${ }^{\text {"20 }}$ Obaveza Grada Varaždina bila je platiti lijevanje u zagrebačkoj Umjetničkoj akademiji. ${ }^{21}$

Već je sljedeće godine I. Meštrović s braćom Krizman razgledao Varaždin i odredio da lokacija postavljanja spomenika bude površina između franjevačke crkve i Petrovićeve kuće, današnje palače Hercer Gradskog muzeja Varaždin. Društvo za proljepšanje grada Varaždina predložilo je da se spomenik postavi

16 HDA, OIV, PS 1932. Na dokumentu oznaka: 32(?)/ 1932.

17 HDA, OIV, PS 1932. Na dokumentu oznaka: Pov. br. 11/ 932.

18 Više o zbivanjima u Varaždinu između dva svjetska rata vidi u: Vladimir HuzJAN, Varaždin $i$ vojska u međuratnom razdoblju (1918. - 1941.), Hrvatska akademija znanosti i umjetnosti, Zagreb - Varaždin, 2017.

19 Bivša supruga I. Meštrovića Ruža, rođ. Klein, bila je Varaždinka (op. a.).

20 Krešimir Fılıć, Odlazak Grgura Ninskog iz Varaždina?, Varaždinske vijesti, 29. siječnja $1969 ., 8$.

21 Mirjana DučA KıJEvić, Varaždin 1931. godine i Grgur Ninski. 80 godina od svečanog postavljanja skulpture Ivana Meštrovića, izložba od 6. listopada do 6. studenoga 2011., Galerija starih i novih majstora, Gradski muzej Varaždin, Varaždin, 2011. 


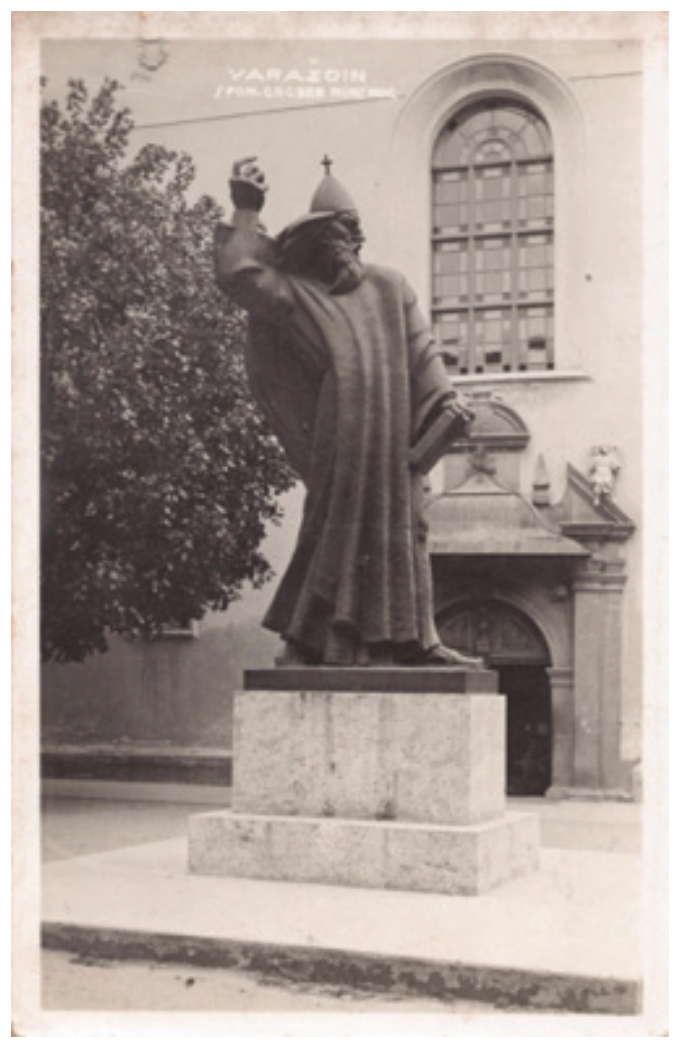

SLIKA 2. Razglednica Varaždina iz 1930-ih s prikazom skulpture Grgura Ninskog (Zbirka Alena Hajcmana)

ispred župne crkve sv. Nikole, ali je ipak prihvaćena autorova sugestija. „Svi obrazovani Varaždinci obradovali su se na ovu vijest jer su znali da je dostojan svake hvale i uveličanja čovjek kome se postavlja spomenik kao i čovjek koji ga je zamislio, zadjelao i stvorio.“22 Dapače, gradski proračun za 1929. - 1930. izglasan je s parolom: „Bez Grgura nema proračuna.“23

Kao priprema za postavljanje spomenika, u lokalnom tisku pojavile su se pjesme u čast Grguru Ninskom, pisalo se o političkoj i crkvenoj povijesti Hrvatske u 10. stoljeću, glagoljici, zatim o biografiji I. Meštrovića, postupku izrade spomenika, a i o protivnicima postavljanja. „Motivi su bili najrazličitiji: neznanje i neupućenost, zloba i pokvarenost i prava nepatvorena bedastoća! Made in Varaždin. “24

22 Grgur Ninski, Varaždinske novosti, 19. veljače 1921., 1.

23 Grgur Ninski i njegovi protivnici u Varaždinu, Varaždinske novosti, 17. rujna 1931., 4.

24 Grgur Ninski i njegovi protivnici u Varaždinu, Varaždinske novosti, 17. rujna 1931., 4. 


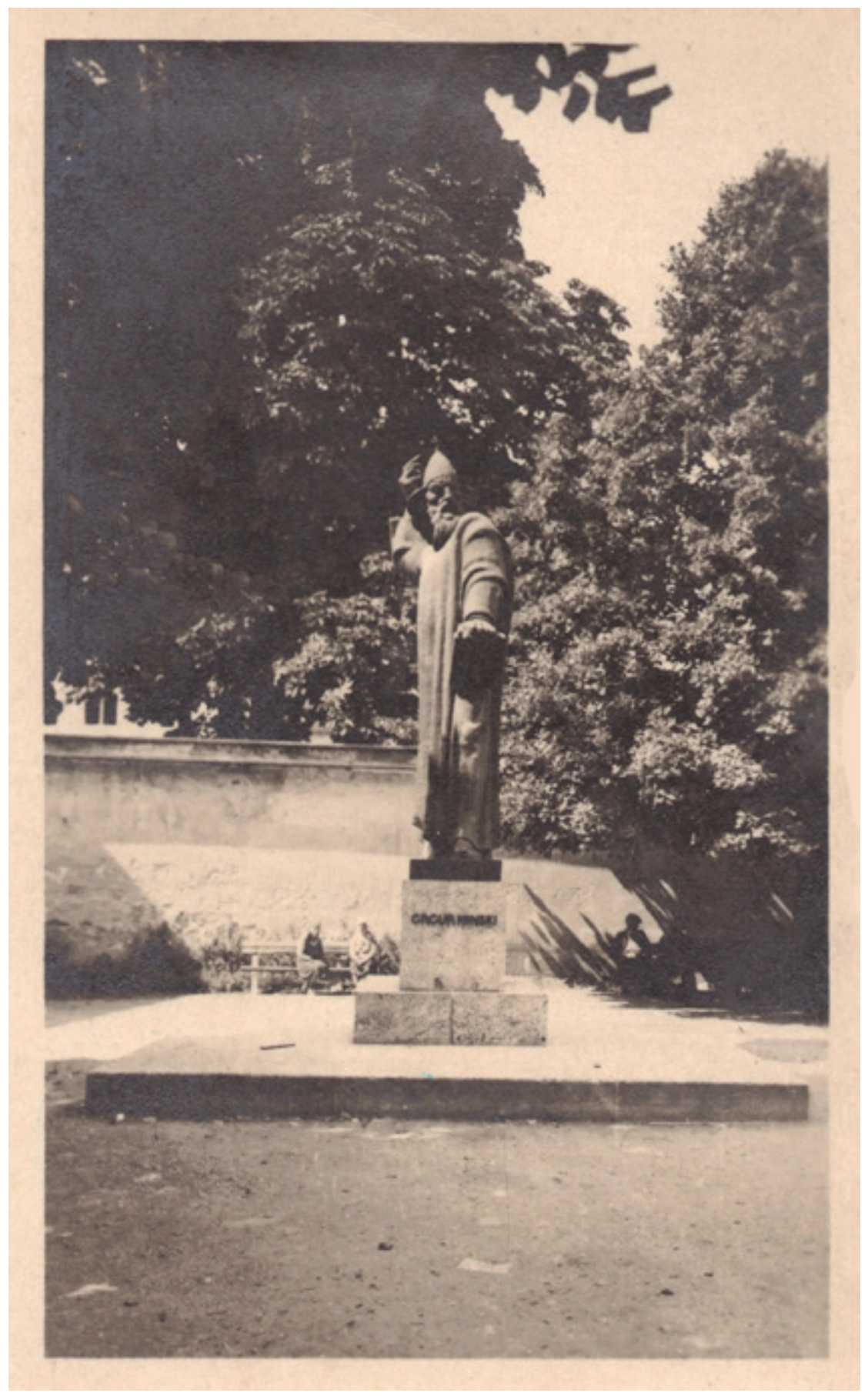

SLIKA 3. Razglednica Varaždina s prikazom skulpture Grgura Ninskog (Zbirka Alena Hajcmana) 
Svečanost otkrivanja spomenika održana je 20. rujna 1931. godine. ${ }^{25}$ Prostor je prigodno uređen, a uz građanstvo i lokalne udruge svečanosti su prisustvovali izaslanik Jugoslavenske akademije znanosti i umjetnosti Gavro Manojlović (1856. - 1939.), izaslanik Zagrebačkog sveučilišta Edo Lovrić (1866. - 1951.), izaslanik I. Meštrovića Jozo Kljaković (1889. - 1969.) i drugi ${ }^{26}$ Ivan Meštrović nije prisustvovao ceremoniji otkrivanja spomenika jer je bio u Splitu. Prvi pozdravni govor održao je zagrebački nadbiskup Antun Bauer (1856. - 1937.) i blagoslovio spomenik, a svečano ga je otkrio tadašnji gradski načelnik D. Perko. Za svoje zasluge I. Meštrović proglašen je počasnim građaninom, a njegova skulptura ostala je do danas najznamenitijom skulpturom u Varaždinu. ${ }^{27}$

\section{U NOVIJE VRIJEME}

Početkom 1969. spomenuti ravnatelj Gradskog muzeja Varaždin K. Filić objavio je u Varaždinskim vijestima članak pod naslovom: „Odlazak Grgura Ninskog iz Varaždina? “28 U njemu je prenio vijest iz Vjesnika od 28. prosinca 1968. kako će Grad Varaždin navodno darovati spomenik Ninu da bi se uzvisila proslava 900-godišnjice povelje kralja Petra Krešimira IV. U članku je zaključeno kako je spomenik dar Gradu Varaždinu i da se nikako ne može darovati nekome drugome. Predlaže da se napravi odljev i takav pošalje u Nin. Varaždinski je spomenik ipak manji od splitskog i bolje bi pristajao u Ninu. Ako je i postojao stvarni prijedlog o preseljenju, on se nije ostvario.

U studenom 1990. napravljena je intervencija u prostoru koji okružuje spomenik. Zid iza njega, koji je dio kompleksa Franjevačkog samostana, prigodno je po želji I. Meštrovića bio podignut za tri reda cigle kako bi se Grgur Ninski više istaknuo. No, početkom 90-ih franjevci su izgradili katnicu koja se uzdiže iznad zida. Sljedeća rekonstrukcija Franjevačkog trga bila je 2008. kada je in situ, u tlu ispred Grgura Nisnkog, pronađen gornji dio Ratnog spomenika. ${ }^{29}$

25 Prvotni donji dio postamenta bio je visok $40 \mathrm{~cm}$, gornji dio $85 \mathrm{~cm}$, a sam kip 3,90 metara. Ukupna cijena odljeva i postavljanja iznosila je 178 tisuća dinara, 22 tisuće manje od planiranoga. Grgur Ninski, Varaždinske novosti, 19. veljače 1931., 1.

26 Svečanost otkrića spomenika Grguru Ninskom, Varaždinske novosti, 24. rujna 1931., 1.

27 „Osobito počašćen izborom za začasnog gradjanina našega drevnog grada neobično žalim što sam zapriječen prisustvovati. Radujem se s Vama otkriću spomenika prvoborcu Grguru. Naša radost je uveličana prisustvom i blagoslovom Hrvatskog metropolita Antuna. Meštrović." Svečanost otkrića spomenika Grguru Ninskom, Varaždinske novosti, 24. rujna 1931., 2.

28 Krešimir Fılıć, Odlazak Grgura Ninskog iz Varaždina?, Varaždinske vijesti, 29. siječnja $1969 ., 8$.

29 Vidi izvještaj Marijane Korunek za Hrvatski arheološki godišnjak, br. 5, 2008., 217 - 219. 


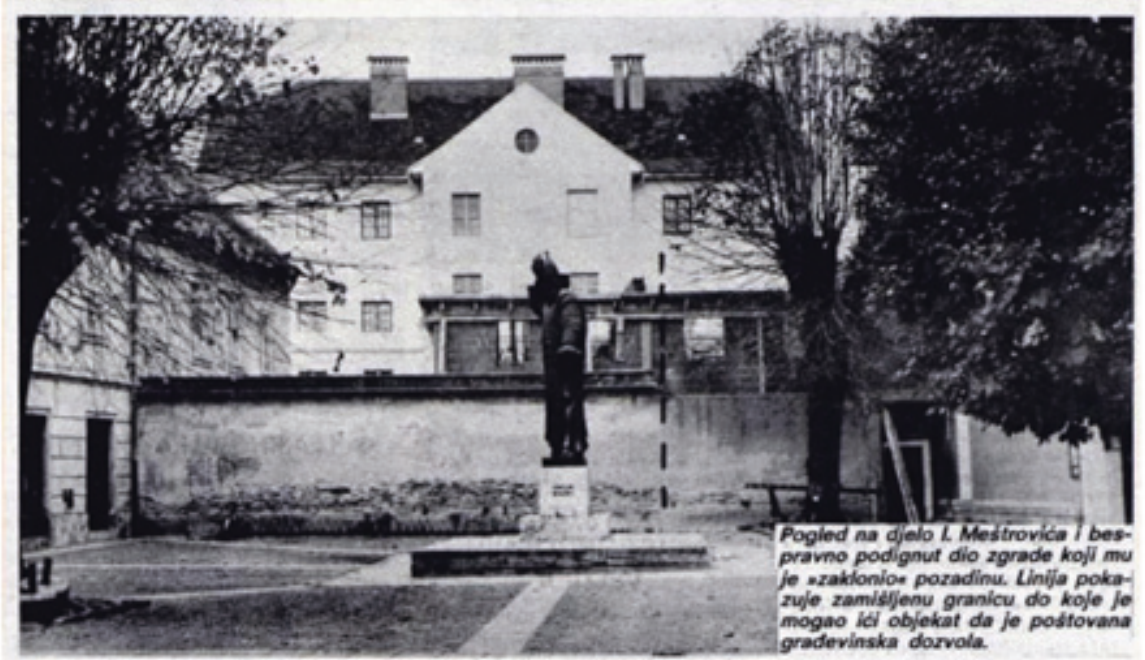

SLIKA 4. Fotografija s komentarom iz Varaždinskih vijesti. (Vlado Premuž, Tajna samostanskog zida, Varaždinske vijesti, 15. studenoga 1990., 13).

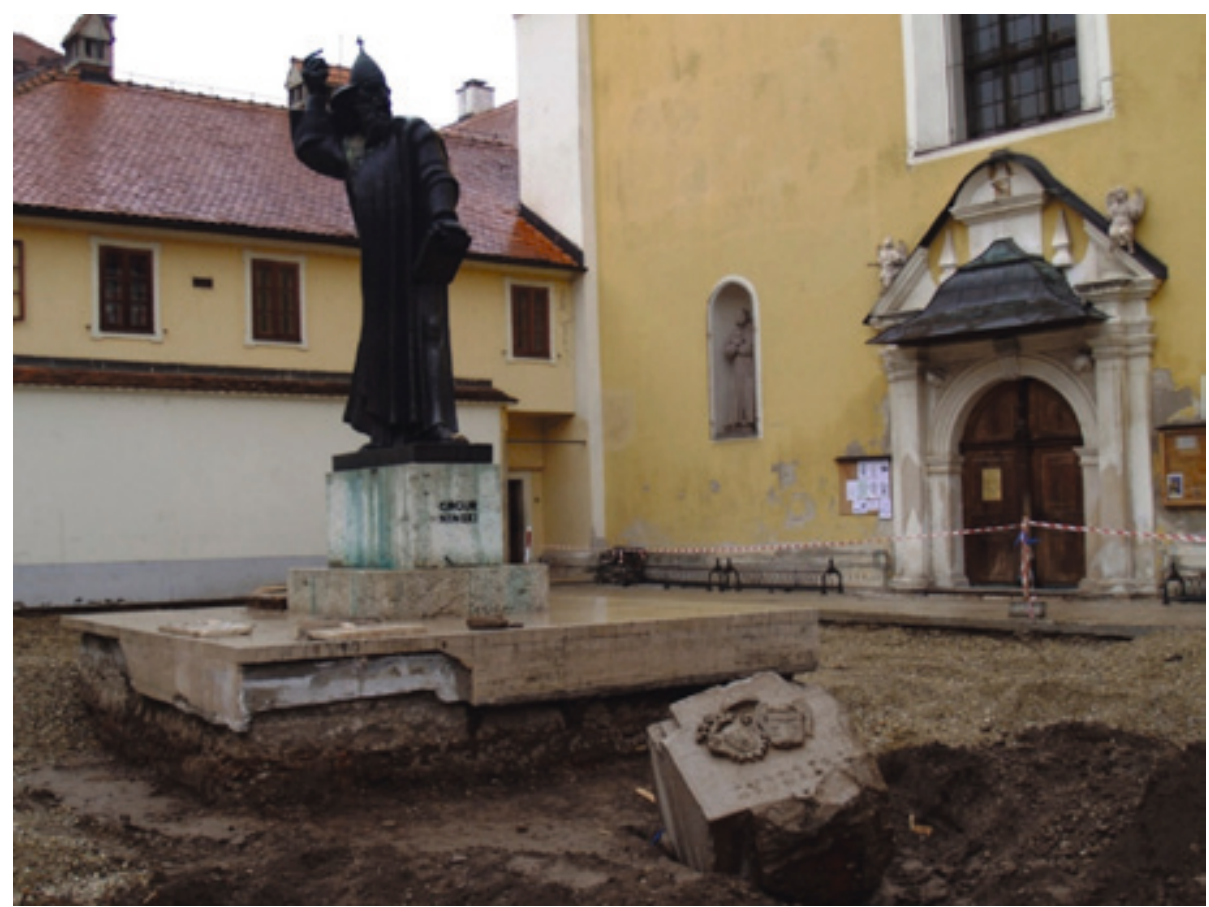

SLIKA 5. Gornji dio Ratnog spomenika in situ 2008. godine (Fotografiju 2008. snimila Marijana Korunek. 


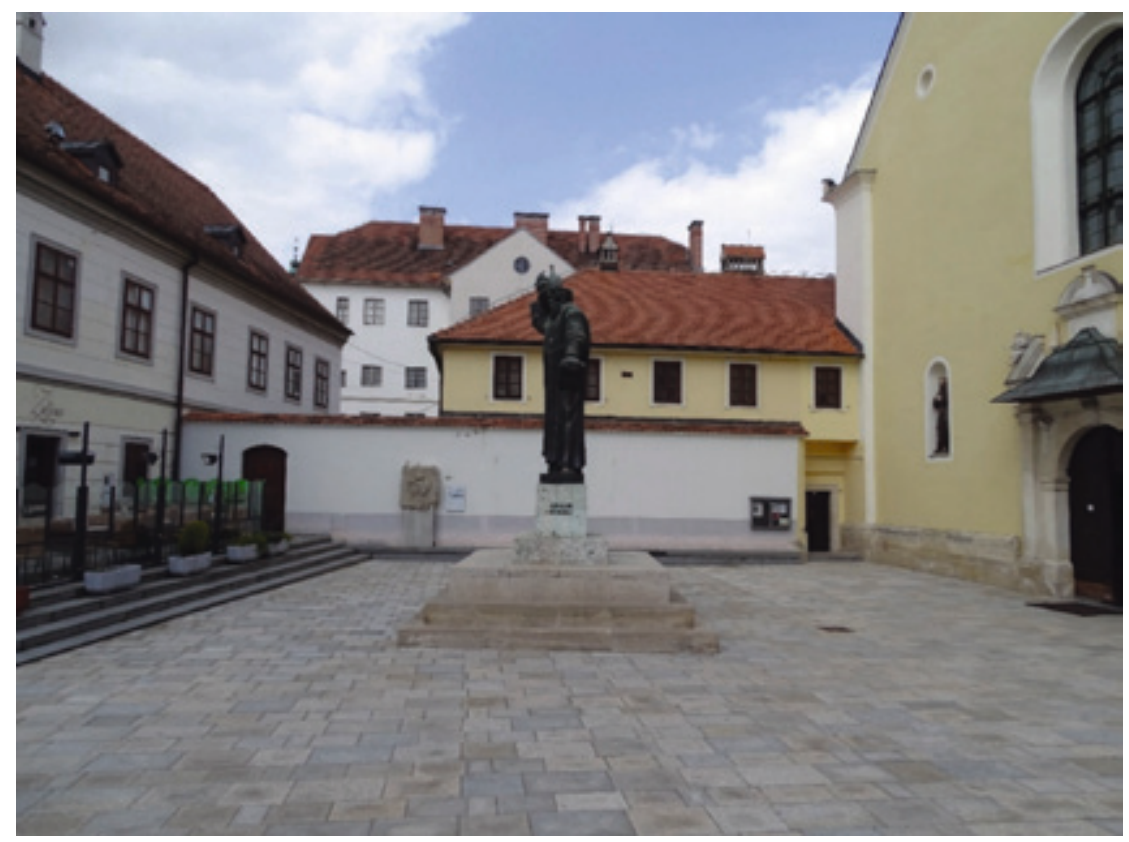

SLIKA 6. Stanje 2019. godine. Lijevo od Grgura Ninskog je na zid Franjevačkog samostana postavljen gornji dio Ratnog spomenika s interpretacijskom pločom (Fotografiju snimio Vladimir Huzjan)

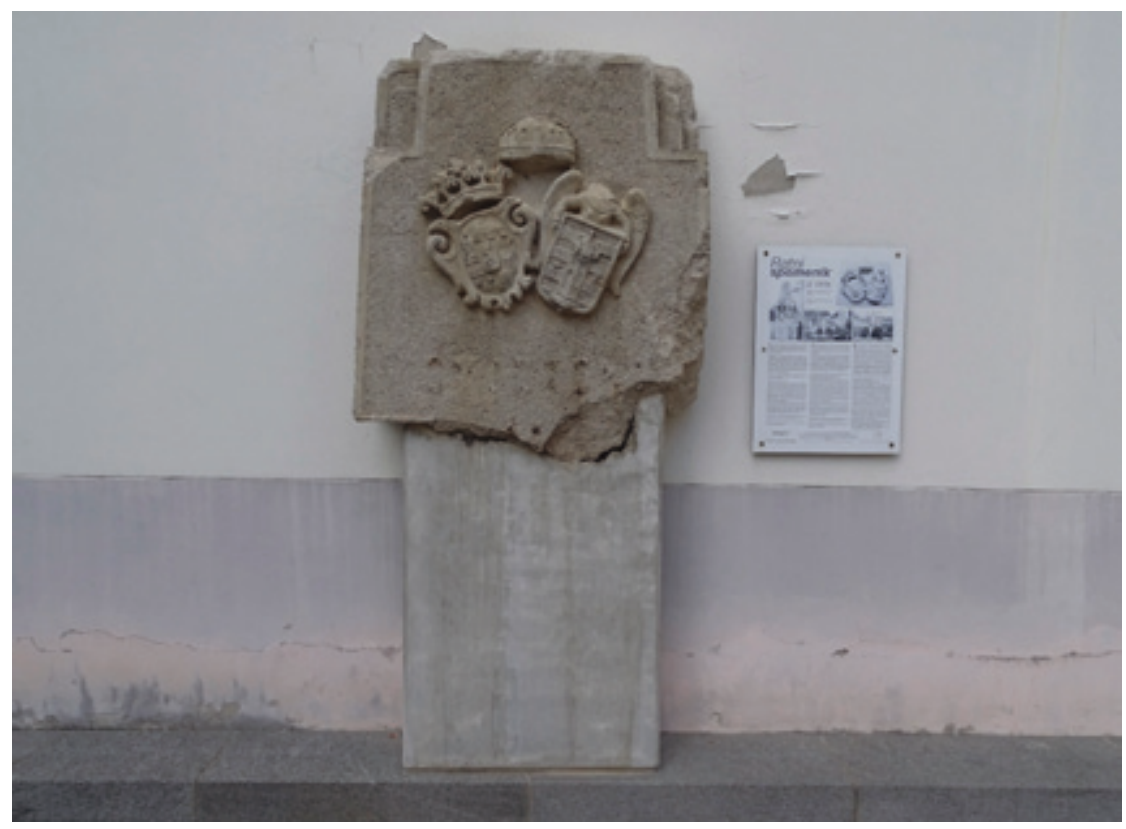

SLIKA 7. Stanje 2019. godine. Ratni spomenik s interpretacijskom pločom (Fotografiju snimio Vladimir Huzjan) 


\section{ZAKLJUČAK}

Jedan manji prostor, kakav je Franjevački trg u Varaždinu, tek je u prvoj polovici 20. stoljeća ukrašen skulpturom. Prvi je bio Ratni spomenik podignut 1915. u čast poginulih vojnika Austro-Ugarske Monarhije. Namjena mu je bila i humanitarna jer su se na njegove drvene površine pribijali čavli koje su kupovali građani. Prikupljeni novac darovan je udovicama i siročadi stradalih vojnika Grada Varaždina i Varaždinske županije. Kada je Veliki rat završio, austro-ugarska obilježja skinuta su sa spomenika, ali je sam spomenik ostao tu do 1931. kada je na njegovo mjesto postavljen Grgur Ninski Ivana Meštrovića. Ovaj spomenik do danas je ostao najmonumentalnijom skulpturom u gradu Varaždinu.

Nakon adaptacije Franjevačkog trga 2008. i arheoloških istraživanja, u podnožju Grgura Ninskog otkriven je ostatak gornjeg dijela Ratnog spomenika s grbovima Grada Varaždina i Varaždinske županije iznad kojih je kruna sv. Stjepana. Taj dio je 2014., u povodu 100. obljetnice početka I. svjetskog rata, uz interpretacijsku ploču stavljen iza Grgura Ninskog na zid Franjevačkog samostana. Tako je Varaždin postao jedan od rijetkih gradova u Hrvatskoj koji je javno predstavio austro-ugarski spomenik iz razdoblja I. svjetskog rata. 
Prilog 1. Pozdravni govor župana Stjepana pl. Beloševića na otkrivanju Ratnog spomenika u Varaždinu iz: Posveta ratnog spomenika, Hrvatsko pravo, 11. prosinca 1915., $1-2$.

„Visoko cijenjeni sjajni sbore! Zapala me častna zadaća, da kao veliki župan i predsjednik Odbora za podignuće ratnog spomenika u gradu Varaždinu isti javnosti predam, koji spomenik želimo dovršiti Vašom pripomoći. Poznato Vam je velecijenjene gospodje i gospodo, da je u obim metropolama nikla, te u većini glavnih kao što i mnogim većim gradovima naše prostrane austro-ugarske monarkije oživotvorena nakana, stvoriti ratne spomenike iz drva u raznolikom obliku, koji se imadu požrtvovnošću općinstva željezom preobući.

Željezno razdoblje — željezni spomenici. Ta baš u tome i leži duboka simbolika. Jer kao što ima iz mekanog drva - naše hrvatske lipe — postati mjedeni spomenik, tako je ovim svjetskim ratom miroljubiv, radini i veseli hrvatski narod očeličao, prkoseć u herojskoj borbi poput tvrde zaštitne pregrade na svim ratištima premoći neprijatelja u ovom užasnom željeznom hrvanju. $U$ toj orijaškoj borbi krijepi naše junake nepokolebiva odanost prema svom ljubljenom kralju i vruća ljubav domovini. U nami je već dulje vremena dozrela misao da ne možemo ni u tom pogledu zaostati za drugima, nu podjedno nam bijaše jasno, da ne smijemo oponašati ine gradove. Pak pošto je njegovo ces. i kralj, apostolsko Veličanstvo naš premilostivi kralj i gospodar Franjo Josip I. koji je prije 67 godina sjeo na sjajno priestolje svojih pradjedova - blagoudostojao g. 1849. premilostivo utemeljiti vojnički krst za zasluge, to je odbor jednodušno zaključio da ovaj naš ratni spomenik neka predstavlja takav vojnički krst, na kojim su osim razdoblja ovog svjetskog rata uklesani grbovi slavne i starodrevne županije i najstarijeg u Hrvatskoj slob. i kr. grada Varaždina. Ovaj spomenik neka sjeća poznije naraštaje, da je ovaj veliki svjetski rat bio s naše strane borba za pravdu i istinu. Mogu li naši mnogi neprijatelji isto reći o sebi i o svojoj borbi? Zar možda srbijanski naručitelji potajnih umorstva ili perfidni sinovi Albiona? Zar možda potlačeno roblje Rusije sve do onog posljednjeg neprijatelja kojeg ja ime u ovom svečanom času neću niti da izustim, jer je i žigosano za sva vremena, a koji je dapače svoju zločinačku ruku pohotno pružio i za našom svetom hrvatskom grudom, za našim sinjim morem, kojega niti jedan Hrvat ne može pojmiti, jer za njegovu odurnu podlost, neima rieči u doličnom jeziku poštenoga naroda! Nu ovaj spomenik uzvisuje još i plemenita svrha kojoj je namijenjen. Mnogi su doprinieli u patriotičrm svrhu pod lozinkom: „Zlato dadoh za željezo”. Naše geslo glasi: „Željezo neka postane zlatom!" Svaki bo čavao koji će se zabiti u ovaj spomenik, dar je za privredno nesposobne junake županije varaždinske i grada Varaždina, za najmilije što su naši junaci ostavili, za njihove udove i sirotčad!

Visoko cijenjeni sbore! Ako naš grad okitimo zastavama, a naša srca radosno zakucaju, kad do nas dopiru vijesti o sjajnim pobjedama koje je izvojevala naša junačka vojska tada nam se pričinja "pobjeda“ kao nešto neosobnog, jer mi vidimo kod riječi pobjeda, samo lepršanje naših trobojnica te slušamo vesele koračnice i burne fanfare. 
Nu mi nećemo zaboraviti, da su sve ove pobjede na čast naše domovine skupo plaćene, mi nećemo zaboraviti da sa svakim srcem junaka, koje je prestalo kucati na bojnim poljanama, krvare srca onih koji izgubiše svoje najmilije. Tada približit ćemo se s osobitim pietetom ovome spomeniku, ne da doprinosimo žrtve, - ne, čedno zahvalna srca, usrećeni što smo se mogli barem donekle odužiti. To je duboki smisao ovog svečanog časa u kojem svi prisižemo: „Na Vas mili junaci naši, da Vaše udovice i siročad ne ćemo nikad zaboraviti.“ A grad Varaždin i županija varaždinska držati će ovu svetu prisegu. Mnogo njezinih sinova prolilo je krvcu za svog kralja i domovinu, a mnogi će ju jošte žrtvovati. Mnogome, koji je danas živ i zdrav oviti će boginja pobjede zeleni lovor vijenac o njegovo ledeno čelo. Ali oni koji kod kuće ostanu, žele doprinijeti, da se zacijele rane, koje je uzrokovao ovaj užasni rat! Već danas će svaki zlatni čavao koji će se zabiti, zasvedočiti zlatna srdca gradjanstva ovoga grada i općinstva ove županije. Nu svaki pa i najmanji dar, izpuniti će namijenjenu svrhu, te će nam dobro doći, jer će otrti suze onomu, koji si niesu kadri sami pomoći ili kojima je ugrabljen hranitelj. Odbor je svoju glavnu zadaću izpunio, a što sijedi - biti će Vaše djelo!

Predajem sada velemožnom gospodinu varaždinskom gradsk. načelniku ovaj spomenik u trajnu pažnju i zaštitu gradske općine, neka isti još nakon mnogo i mnogo godina svjedoči o požrtvovnosti gradjanstva ovog starodnevnog grada i općinstva slavne ove županije, da će naši potomci kad ga ugledaju kazati : „Godine 1914., 1915. i 1916. bijahu za nas Hrvate godine teške bijede i kušnje, nu takodjer i godine slave i spasa. Da Bog poživi Njegovo Veličanstvo našeg premilostivog cara i kralja Franju Josipa I!“

Prilog 2. Govor zagrebačkog nadbiskupa Antuna Bauera u povodu otkrića spomenika Grguru Ninskom u Varaždinu iz: Svečanost otkrića spomenika Grguru Ninskom, Varaždinske novosti, 24. rujna 1931., 1.

„Hrvatski je narod za tisućgodišnjeg narodnog i državnog života svoga proživljavao teških i mučnih vremena. Tako je bilo i u X., a naročito u XI. vijeku kad se zaoštrila borba oko upotrebe slavenskog jezika u bogoštovlju i kad su nastale utakmice i sporovi o preeminenciji pojedinih biskupija. U to vrijeme pada biskupovanje Grgura Ninskog. $\mathrm{Na}$ žalost su historijski spomenici o tom vremenu mutni i nedostatni, te o životu i radu Grgura Ninskoga znademo vrlo malo, no koliko god su ti spomenici oskudni, troje sasvim nesumnjivo posvjedočuju: da je Grgur bio biskup, koji se je u bogoštovlju služio slavenskim jezikom, da je on kao ninski biskup imao težak spor sa metropolitom splitskim, jer je htio ninskoj biskupiji pridobiti metropolitansku samostalnost i vlast nad svom Hrvatskom i napokon, da je on bio uvijek vjeran crkvi katoličkoj i odan apostolskoj stolici u Rimu, pak i onda, kad su se latinski biskupi koji su bili pod okriljem Bizanta, nalazili pod jurisdikcijom bizantskog patrijarhe. Nastojanje i borba Grgura Ninskoga za 
metropolitansku vlast završila se pobjedom splitskog metropolite te je dapače i Ninska biskupija dokinuta, a Grgur dobio Skradinsku biskupiju.

U to doba začela se i borba oko baštine sv. Ćirila i Metoda, upotrebe naime slavenskog jezika u bogoštovlju. Ta je borba trajala hiljadu godina i vodila se izmjeničnom srećom. Ali ljubav našega puka prema svome jeziku u službi božjoj i žilavost našeg glagoljaškoga svećenstva, sačuvala nam je tu dragocjenu baštinu, u kojoj su ne samo naši velikani od Križanića, Levakovića, Strossmayera, Dobrile, Posilovića i Mahnića gledali ostvarenje odluke dobrostivog i mudrog promisla Božjega, da ćirilometodska ideja bude kopča i veza između razdijeljene slavenske braće, već su i pape dalekih vidika kao Inocent IV., Urban VIII., Benedikt XIV., Leon XIII. i današnji slavni Pio XI. bili zaštitnici upotrebe slavenskog jezika u bogoštovlju. Tako je naročito sadašnji vrhovni vladar svete Crkve Pio XI. na molbu katoličkog episkopata Jugoslavije rado dozvolio, da se staroslavenski misal tiska latinskim slovima, mjesto teške čitljive glagoljice, i s njegovim je odobrenjem i potvrdom pred dvije godine tiskan na hrvatskom jeziku čitav obrednik kao tipično izdanje kojim se smiju služiti svećenici iz čitave Jugoslavije, gdje god na hrvatskom jeziku obavljaju svete obrede.

Stojeći pred velebnim ovim spomenikom Grgura Ninskoga, što ga je umjetnik svjetskoga glasa, ali uvijek naš Meštrović, izradio, a dragi mi grad Varaždin na ovo mjesto postavio, leti mi pred dušom sva ona teška borba i žilavost, kojom je hrvatski narod znao sačuvati dragocjenu baštinu sv. Ćirila i Metoda, a srce mi ispunja radost kad gledam, da je ta baština danas izvan svake opasnosti, ispunja želje i nade, da će svemogući Bog uskoriti čas, da zavjetna misao Grgura Ninskoga, ćirilometodska ideja zbliži i ujedini udaljene kršćanske crkve. To i hoće da nam govori spomenik biskupa ninskoga i na jugu na žalu sinjeg našeg Jadrana i ovdje na sjeveru naše Jugoslavije. S tim čuvstvima u srcu, sazvati ću sada molitvom svevišnjega da blagoslov njegov čuva i štiti njegovo veličanstvo kralja našega Aleksandra, njegov kraljevski dom i čitavu našu dragu domovinu.“ 
Vladimir HUZJAN

ABOUT ONE SQUARE AND TWO MONUMENTS - THE GREAT WAR AND GRGUR NINSKI

\section{SUMMARY}

A relatively small area, such as Franciscan Square in Varaždin, was decorated with sculptures only in the first half of the 20th century. The first was the War Memorial, erected in 1915 in honour of the killed soldiers of the Austro-Hungarian Monarchy. It was also intended for humanitarian purposes, as nails used to be knocked in in its wooden parts and the residents used to buy them. The money raised was donated to the dead soldiers' widows and children from the City and County of Varaždin. When the Great War ended, Austro-Hungarian symbols were removed from the monument, but the memorial itself remained there until 1931 when Grgur of Nin by Ivan Meštrović replaced it. This monument has been the most monumental sculpture in the city of Varaždin to date.

While reconstructing Franciscan Square in 2008 and conducting research, the remains of the upper part of the War Memorial with the coats of arms of the City and County of Varaždin were unearthed at the foot of Grgur Ninski with a crown of St. Stephen above them. In 2014, on the occasion of the 100th anniversary of the beginning of World War I, this part with an explanation plate was put on the Franciscan monastery wall behind Grgur Ninski. Thus, Varaždin became one of the few towns in Croatia to display an Austro-Hungarian monument from the First World War publicly.

Keywords: Varaždin, World War I, Ivan Meštrović, Artur Kadeŕavek, Grgur Ninski. 
